\title{
Adoption of technology, management practices, and production systems in US milk production
}

\author{
A. R. Khanal, ${ }^{*}$ J. Gillespie, ${ }^{\star 1}$ and J. MacDonald† \\ *Department of Agricultural Economics and Agribusiness, Louisiana State University Agricultural Center, Baton Rouge 70803 \\ †Economic Research Service, 1800 M St. NW, Washington, DC 20036
}

\begin{abstract}
The introduction of new technology, management practices, and alternative production systems has resulted in rapid structural change in the US dairy industry. This paper examines adoption rates and adopter characteristics for the following dairy technologies, practices, and systems: holding pen with an udder washer, milking units with automatic take-offs, genetic selection technologies, recombinant bovine somatotropin, membership in the Dairy Herd Improvement Association, computerized feed delivery systems, computerized milking systems, use of a nutritionist to design feed rations, grazing, milking cows 3 times daily, and milking parlors. Four of these were used on a greater percentage of farms in 2005 than in 2000, but increased farm sizes and the interaction of farm size with adoption suggest a greater percentage of milk being produced under each, with the exception of grazing. Except for grazing, technologies were generally complementary.
\end{abstract}

Key words: technically complementary, technology, management practice, production system

\section{INTRODUCTION}

The United States dairy industry has undergone rapid structural change in recent years, with adjustments occurring at all levels. Although dairy operations have traditionally been heavily dependent upon labor, technological advances have moved the industry toward greater reliance on managerial and technological innovations. Larger, more efficient operations contribute more to the milk production share as small operations exit or expand. This report examines 2000 and 2005 adoption rates of technological innovations, management practices, and production systems in the dairy industry, showing types of farms adopting, complementarity among innovations and practices, and diffusion rates between the 2 years of study.

Received May 10, 2010.

Accepted August 20, 2010.

${ }^{1}$ Corresponding author: jmgille@lsu.edu

\section{Changing Industry Structure}

United States Department of Agriculture data over the period from 1999 to 2008 show an almost tripling of dairy farm numbers in the very large size $(\geq 2,000$ cow) category, from 255 to 730 farms. The percentage of production in this size category increased from 9 to $31 \%$ (USDA-National Agricultural Statistics Service, 2000, 2009). Data over a longer period show that the average US herd size was 19 cows in 1970, rising to 120 in 2006 (MacDonald et al., 2007), with average milk produced per cow doubling and production per farm increasing 12-fold (MacDonald et al., 2007). Figure 1 illustrates the reduction in US dairy cow numbers and the increase in cow productivity from 1990 to 2007. Much of this increased productivity can be attributed to improved management practices, animal selection, and technology adoption.

United States milk production has had its greatest recent growth in the western United States, a nontraditional dairy region given the historic concentration of milk production in the Northeast and Upper Midwest. The tendency for larger, more technologically advanced operations to arise outside of traditional regions is consistent with the evolution of other agricultural industries (Reimund et al., 1977). Short (2004) stresses the role of technology in dairy industry evolution, stating it has "changed the way milk is produced," with firm growth and specialization being made possible by technology. Furthermore, technology has changed the assembly, processing, and distribution of milk (Manchester and Blayney, 1997). Given the role of technology in dairy industry structural change, interest exists in analyzing patterns of technology adoption, its drivers, and its adopters.

\section{Previous Work on Technology Adoption in Dairy Production}

Adoption of technology at the farm level has been extensively studied. Feder et al. (1985) explain that farm decisions result from dynamic processes such as information gathering, learning by doing, and resource accumulation. Immediate and uniform adoption in ag- 


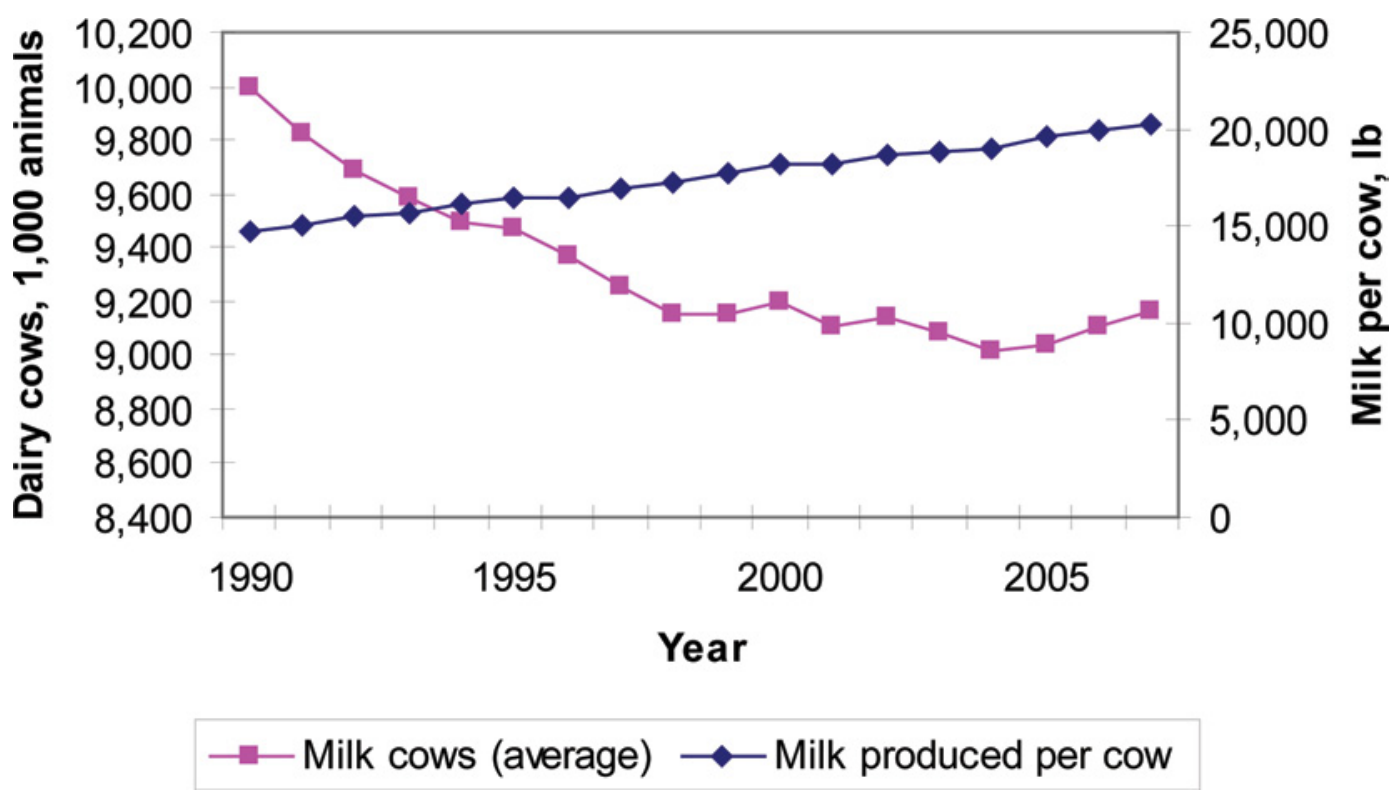

Figure 1. Total US dairy cows and milk per dairy cow, 1990-2007. Source: USDA-National Agricultural Statistics Service. Color version available in the online PDF.

riculture is rare, with rates usually differing across socioeconomic groups and over time (Feder et al., 1985).

Several studies have been conducted to examine technology adoption in US milk production. Highlights include Weersink and Tauer (1991), who showed farms with larger herd sizes to be greater technology adopters. El-Osta and Johnson (1998) showed an association of milk produced per cow with farm profitability. Inferior genetics, low quality feeds, and disease incidence have been limiting factors for cow productivity (Tauer and Mishra, 2006), negatively influencing profit. El-Osta and Morehart (2000) showed that the probability of a farmer being in the lowest quartile of production performance is lower with the adoption of capital- or management-intensive technologies. Production costs in the top performance group were $53 \%$ lower than those in the low performance group (El-Osta and Morehart, 2000). Adoption of dairy farm technology is associated with financial, scale, demographic, and other factors. Large farms adopted the highest percentage of milking units with automatic take-offs and were the most likely to employ a nutritionist and use recombinant bST (rbST) in 2000 (Short, 2004).

This paper examines the types of dairy farms adopting the following dairy farm technologies, management practices, and systems: holding pen with udder washer, milking units with automatic take-offs, genetic selection technologies, rbST, a computerized feed delivery system, a computerized milking system, use of a nutritionist to design feed rations, membership in the DHIA, milking cows 3 times daily, grazing, and a dairy parlor, each defined as follows.

\section{Technological Innovations and Management Practices}

Holding Pen with an Udder Washer. Cow udders may be washed in the holding pen before entering the milking parlor. A variety of udder washer types are available, with systems generally including a water heater with automatic teat spraying systems, spray guns, or teat dipping operations. This contrasts with the traditional method of manually cleaning udders. In $1993,3 \%$ of US dairy farms used udder washers and $71 \%$ of those were operations with $>300$ cows (Short, 2000).

Milking Units with Automatic Take-Offs. Milking beyond the point where the udder has stopped releasing milk results in increased incidence of mastitis and high SCC. Under-milking can result in lower milk yield. Automatic take-offs are sensors used on milking units that indicate the end of milk flow. At the end of milk flow, the automatic take-off shuts off the vacuum and releases the milking unit from the udder; the milking unit is automatically removed from underneath the cow. Automatic take-off equipment, mechanical or electronic, varies in type and style, with most equipment as shown on Internet Web sites available for $<\$ 1,000$ per milking machine. In parlors, automatic take-off use can increase operator comfort (by reducing deep-knee 
bends) and increase the number of cows milked per laborer (Tranel, 2008).

Breeding Technologies as a Part of Genetic Selection. Shook (2006) suggests that improved genetics has accounted for $55 \%$ of the gain in milk yield and one-third of the reduction in time to conception. Improved genetic selection can be accomplished through AI, embryo transfer (ET), or traditional breeding methods. Both AI and ET allow for selection of specific traits by increasing the available gene pool.

In AI, sperm are collected, processed, stored, and artificially introduced into the female. Upon the introduction of $\mathrm{AI}$ in the 1940s, dairy breed and herd improvement associations supported extension services in promoting its use (Johnson and Ruttan, 1997). Artificial insemination developed as a solution to the need for genetic improvement, as well as the elimination of costly venereal diseases (Foote, 1996). Economic advantages of AI have been shown by Hillers et al. (1982), Barber (1983), and Busem and Bromley (1975).

Sexed semen technology further involves separation of sperm into male/Y-bearing and female/X-bearing sperm cells and then artificially inseminating. Although a calf of specific sex can be produced (DeVries et al., $2008)$, the lower conception rate (35-40\% with sexed semen, $55-60 \%$ otherwise) is a limitation (Weigel, 2004). Due to continued improvements in sorting capacity and fertility, DeVries et al. (2008) expect sexed semen technology to be "widely used within the next decade."

Using ET, embryos are collected from a donor female and transferred to recipient females. Multiple eggs may be obtained from a cow via hormone administration (superovulation), even with young heifer calves. These superovulated, generally more valuable, donor cows are then inseminated, and embryos are allowed to grow for 4 to $5 \mathrm{~d}$ before being transferred to relatively less valuable recipient cows (Tyler and Ensminger, 2005).

Although AI provides the opportunity to reduce the number of sires needed for selection in the subsequent generation, ET similarly reduces the number of dams needed. Sexed semen use can lead to higher genetic merit of newborn calves (van Arendonk and Bijma, 2003). Its use has been limited to a relatively small number of highly marketable animals (Weigel, 2004).

Recombinant $\boldsymbol{b S T}$. Recombinant bST was released commercially in 1994. Currently marketed by Elanco Animal Health Services (Greenfield, IN), it has been considered a scale-neutral technology. Using rbST, farmers could expect about an additional $10 \mathrm{lb}$ (4.54 $\mathrm{kg}$ ) of milk per day with use, and the cow's lactation could be extended with use. The Eli Lilly Elanco Animal Health Services Web site (http://www.elancodairy. com/about/benefits/index.html; accessed July 13, 2009 ) lists the price of 1 dose, given every $14 \mathrm{~d}$, at $\$ 6.60$.
Although many initially expected extensive adoption of rbST, adoption has been modest, probably because of the following factors: research has not shown significant increases in farm profitability with its use (Foltz and Chang, 2002; McBride et al., 2004; Tauer, 2005), consumer controversy over its use, and growing markets for organic and "natural" milk and dairy products.

DHIA Membership. The DHIA is a voluntary, feebased, recordkeeping service that allows dairy farmers to track production. In the United States, DHIA participation has been associated with increased production efficiency and profitability, but the high turnover rate without a large increase in enrollment has been a problem (Spain and Witherspoon, 1994). McCaffree et al. (1974) found that economic returns increased with consecutive years of participation, so short participation periods may prevent participants from fully realizing the economic value of DHIA membership. Northeastern and Midwestern herds have had the longest tenures in DHIA (Hare et al., 2004).

Computerized Feed Delivery Systems. Feed cost accounts for the largest share of milk production costs, thus improved feed utilization can significantly affect profit. To reduce labor costs, dairy feeding systems are becoming more automated. One approach uses an integrated computerized cow identification system that feeds according to energy needs, depending upon lactation phase (Kelly, 2001). Kelly (2001) describes automated systems as either (1) variable-time feeding, which allots feed proportional to time, or (2) fixed-time routines, which use fixed feeding intervals for all cows in the herd. The software controlling automatic concentrate feeding may also adjust automatically for factors such as milk production and lactation stage and can deliver feed at the eating speed of the individual cow (Kelly, 2001).

Computerized Milking Systems. Computerized milking systems can be applied in several ways. Automated robotic milking systems (AMS) range from systems that merely automate attachment of cups to teats to fully automatic systems. The AMS is usually linked to an automated concentrate feeding system and may have an attached automatic cleaning system (Kelly, 2001). According to Rotz et al. (2003), many AMS are used in Europe with just a few in the United States. Gillespie et al. (2009a) contains more information regarding computerized milking systems.

Using a Nutritionist to Design Mixes or Purchase Feed. Understanding and providing better nutrition furnishes an immediate means of improving cow health and milk yield. Improved feed management can reduce the excretion of specific nutrients in manure (Harrison et al., 2007). The USDA-Natural Resources Conservation Service has defined Feed Management 
Practice Standard 592 as managing "the quality of available nutrients fed to livestock and poultry for their intended purpose." A 5-step implementation process for this practice has been developed (White et al. 2007), with each including a nutrient management planner or nutritionist as a participant.

\section{Housing and Milk Production Systems}

Grazing. Grazing for provision of forage in a dairy operation can range from minimal to extensive, inwhich pasture furnishes the majority of forage needs during the grazing season. We provide a limited picture of grazing activity, not distinguishing between slight and extensive pasture use, but only whether grazing is utilized. Increased interest in pasture-based dairying has emerged due to increased demand for "natural" milk products and the fact that some pasture-based operations may qualify as organic with additional management changes.

Studies finding pasture-based operations to be competitive or potentially competitive with conventional dairy production include Tucker et al. (2001) and White et al. (2002), both of which compared pasture-based operations only with conventional operations of a similar (small) size. Gillespie et al. (2009b) found profitability of pasture-based versus conventional systems to depend partly on the extent of pasture use. Pasturebased systems are unlikely to be feasible in most largescale operations because of the high land costs and the distances that cows might have to move to reach the milking parlor.

Three-Times-Daily Milking. To more efficiently use parlors and increase production per cow, some farmers milk cows 3 times daily. Studies have shown a 6 to $19 \%$ increase in production associated with a third milking (Amos et al., 1985; DePeters et al., 1985; Gisi et al., 1986). The yield response, however, appears to be fixed rather than a percentage (Erdman and Varner, 1995). An additional advantage to milking 3 times daily is that it partially solves the problem of milk quality deteriorating in the late stages of lactation to the point where it cannot be used for cheese (Sorensen et al., 2001). A disadvantage is the inverse relationship between reproductive efficiency and time the cow spends getting milked (Gisi et al., 1986).

Parlor. On most large-scale and some smaller dairies, milking is conducted in parlors. In a parlor system, cows enter stalls for milking, generally on a raised platform. Parlor arrangements include herringbone, parallel, swing, side opening, polygon, flat, and others. Automated flat parlors may result from small farmers transitioning from stall to freestall housing (Chastain and Reinemann, 1995). An alternative to the parlor system is the stanchion or tiestall barn, generally using bucket milkers or around-the-barn pipeline systems. Stanchion systems, generally used on smaller farms, tend to require more labor. For small farms, the cost of stanchion technology is generally lower than that of parlor technology (Tauer, 1998; Katsumata and Tauer, 2008). Tauer (1998) found parlor technology to be more cost efficient in barns with $>160$ cows, suggesting significant associated economies of size.

\section{MATERIALS AND METHODS}

This study uses data from the 2000 and 2005 Agricultural Resource Management Survey (ARMS) dairy version, conducted by the USDA National Agricultural Statistics Service (NASS) and Economic Research Service (ERS). The 2000 and 2005 data sets include 870 and 1,814 observations, respectively. The minimum size for inclusion was 10 cows, to limit the sample to what are believed to be commercial observations. States covered include Arizona, California, Florida, Georgia, Idaho, Illinois, Indiana, Iowa, Kentucky, Maine (2005 only), Mississippi, Minnesota, Missouri, New Mexico, New York, Ohio, Oregon (2005 only), Pennsylvania, Tennessee, Texas, Vermont, Virginia, Washington, and Wisconsin.

The survey collects information on farm operator and financial characteristics, production costs, size, commodities produced, and technology use. Sample dairy farms are selected from a list maintained by NASS. Sampling is stratified, with sampling probabilities varying by farm size and state to achieve more reliable estimates of production and expenses. Each sample farm represents several like farms in the population, and expansion factors allow for extrapolation to the dairy farm population of the 24 states where the survey was conducted (90\% of the US dairy farm population). Estimates for 2000 and 2005 are comparable because of consistency in surveying and processing the data: collected by the same organization in a similar format using hand enumeration, involving a complex sampling scheme, and representing the same population with broad national coverage.

With 2,684 observations in the combined 2000 and 2005 ARMS dairy surveys, pair-wise, 2-tailed $t$-tests utilizing the delete-a-group jackknife estimation procedure were used to determine whether significant differences existed between adopters and nonadopters. We considered (1) farm and operator characteristics, including number of milk cows, farm operator age, and whether the principal operator holds a 4-yr college degree; (2) enterprise performance measures, including milk yields and debt:asset ratios; and (3) clustering of technologies - the extent to which adopters and non- 
adopters use combinations of other technological innovations, management practices, or production systems. Although initially considered as potential factors of interest, specialization variables such as percentage of value of farm production from dairy and whether homegrown feeds were fed were not found to differ between adopters and nonadopters of technology; therefore, they were not included in the results. Likewise, regional differences were not considered because they are likely to be highly correlated with farm size, of which measures are provided. Using the jackknife, there were 15 replicates and 28 degrees of freedom. For greater detail on this estimation procedure using ARMS, the reader is referred to Dubman (2000).

\section{RESULTS}

We report findings in Tables 1 to 4 . Table 1 reports comparisons of adoption rates for each of the technologies in 2000 and 2005. Because dairy production is skewed toward the largest farms, we report adoption rates in 2 ways, as the proportion of farms adopting a technology and as the proportion of production covered by farms using the technology (i.e., the latter weighted by production). In Table 2, we compare adopters and nonadopters of each technology, management practice, or system in each of the 2 years. In Table 3, we compare adopters and nonadopters of AI and ET (with or without sexed semen) for 2005 only, because these technologies were not separated for analysis in 2000. Table 4 reports results showing complementarity of adoption among technologies.

\section{Adoption Diffusion}

Significant adoption diffusion was found for 4 technologies or production systems from 2000 to 2005 (Table 1 ). The percentage of farms adopting (1) milking units with automatic take-offs increased from $24.4 \%$ in 2000 to $37.5 \%$ in $2005,(2)$ genetic selection increased from $64.3 \%$ in 2000 to $81.5 \%$ in 2005 , (3) 3-times-daily milking increased from $3.4 \%$ in 2000 to $6.9 \%$ in 2005 , and (4) parlors increased from $38.2 \%$ in 2000 to $49.9 \%$ in 2005. It is noted that the latter 2 production systems were particularly associated with the adoption of many of the other technologies, a subject of later discussion when we discuss complementary relationships among technologies.

Of note are the technologies, management practices, and production systems for which percentages of farms adopting did not change from 2000 to 2005: holding pens with udder washers, rbST, DHIA membership, computerized feeding systems, computerized milking systems, use of a nutritionist, and grazing. The lack of change in rbST and grazing may be partially explained by increased consumer demand for milk with specific attributes, such as rbST-free and organic, trends not expected to greatly influence the other technologies.

\section{Adoption and Farm Size}

We also report the percentage of production covered by farms using each technology, shown in Table 1. Because larger farms are typically greater adopters of technology, these weighted adoption rates are expected to exceed percentages of farms adopting. In general, that is true, with the exception of grazing. Particularly large differences in adoption rates appear for milking systems (use of holding pens with udder washers, automatic take-offs, computerized milking systems, parlors, and milking frequency). This pattern suggests significant economies of size with the more capital-intensive technologies. Furthermore, in the case of the farm size variable number of cows (Tables 2 and 3), larger farms were greater adopters of all technologies, management practices, and production systems except for grazing. The differences in farm size between adopters and nonadopters in 2005 were greater than those in 2000 for all technologies. Our findings with regard to spread of technologies did not change when we relied on share of production covered by farms adopting a technology: important increases between 2000 and 2005 were still observed for automatic take-offs, genetic selection, and milking frequency.

\section{Adoption and Farmer Demographics}

Analysis of farmer demographic variables showed significant differences between adopters and nonadopters (Tables 2 and 3). Adopters of ET with or without sexed semen, rbST, and those who used nutritionist services were younger than nonadopters by at least $4 \mathrm{yr}$ each, whereas adopters of grazing were older than nonadopters in 2005. Education results were particularly striking, with adopters of all technologies, management practices, and production systems other than automatic take-offs, computerized milking systems, and grazing being more likely to hold college degrees than nonadopters in at least 1 yr. In some cases, the differences were quite large. For example, in 2005, 25.2\% of automatic takeoff adopters held college degrees compared with $10.6 \%$ of nonadopters; $39.1 \%$ of farmers milking 3 times daily held college degrees compared with $14.4 \%$ of nonadopters; and $40.8 \%$ of ET/sexed semen adopters held college degrees compared with $13.2 \%$ of nonadopters. 
Table 1. United States Department of Agriculture Agricultural Resource Management Survey dairy farm size, demographic, and technology estimates; weighted means by year ${ }^{1}$

\begin{tabular}{|c|c|c|}
\hline Item & 2000 & 2005 \\
\hline Farms, n & $71,300^{\mathrm{a}}$ & $52,237^{\mathrm{b}}$ \\
\hline \multicolumn{3}{|l|}{ Farm size } \\
\hline Milk cows, $\mathrm{n}$ & $112^{\mathrm{b}}$ & $154^{\mathrm{a}}$ \\
\hline \multicolumn{3}{|l|}{ Farmer demographics } \\
\hline Farmer age, yr & $49^{\mathrm{b}}$ & $51^{\mathrm{a}}$ \\
\hline Farmer college degree, $\%$ & $10.4^{\mathrm{b}}$ & $16.1^{\mathrm{a}}$ \\
\hline \multicolumn{3}{|l|}{ Technologies: US farms adopting, $\%$} \\
\hline Holding pen with udder washer & 5.4 & 6.5 \\
\hline Milkers with automatic take-offs & $24.4^{\mathrm{b}}$ & $37.5^{\mathrm{a}}$ \\
\hline Genetic selection & $64.3^{\mathrm{b}}$ & $81.5^{\mathrm{a}}$ \\
\hline AI & $\mathrm{NA}^{2}$ & 81.4 \\
\hline Embryo transfer and/or sexed semen & NA & 10.4 \\
\hline Recombinant bST & 17.3 & 16.6 \\
\hline DHIA membership & 44.7 & 45.4 \\
\hline Computerized feeding system & 8.1 & 7.1 \\
\hline Computerized milking system & 6.1 & 5.3 \\
\hline Nutritionist used & 66.9 & 71.6 \\
\hline Grazing & 68.5 & 64.5 \\
\hline Milk 3 times per day & $3.4^{\mathrm{b}}$ & $6.9^{\mathrm{a}}$ \\
\hline Parlor & $38.2^{\mathrm{b}}$ & $49.9^{\mathrm{a}}$ \\
\hline \multicolumn{3}{|c|}{ Technologies: US production (\%) by farms using: } \\
\hline Holding pen with udder washer & 26.8 & 31.5 \\
\hline Milkers with automatic take-offs & 58.3 & 73.0 \\
\hline Genetic selection & 76.2 & 89.0 \\
\hline $\mathrm{AI}$ & NA & 88.9 \\
\hline Embryo transfer and/or sexed semen & NA & 15.7 \\
\hline Recombinant bST & 35.0 & 40.0 \\
\hline DHIA membership & 57.0 & 58.5 \\
\hline Computerized feeding system & 21.6 & 28.3 \\
\hline Computerized milking system & 19.7 & 22.7 \\
\hline Nutritionist & 83.2 & 87.7 \\
\hline Grazing & 46.0 & 36.9 \\
\hline Milking 3 times per day & 19.0 & 30.2 \\
\hline Parlor & 70.0 & 83.8 \\
\hline \multicolumn{3}{|l|}{ Other } \\
\hline Debt:asset ratio & $0.19^{\mathrm{a}}$ & $0.15^{\mathrm{b}}$ \\
\hline Milk per cow, cwt/yr & $156.11^{\mathrm{b}}$ & $168.94^{\mathrm{a}}$ \\
\hline
\end{tabular}

${ }^{\mathrm{a}, \mathrm{b}}$ Means within rows with different superscripts differ, $P<0.10$.

${ }^{1}$ The $t$-statistics are based on 1,804 observations using weighting techniques described in the Dubman (2000) program.

${ }^{2} \mathrm{NA}=$ not available.

\section{Adoption and Its Relationship with Productivity and Debt Load}

Adopters of all technologies, management practices, and production systems other than grazing achieved higher milk production per cow than did nonadopters (Table 2). Readers are cautioned to not ascribe cause and effect interactions among any of the variables because this analysis was not multivariate in nature. This is particularly important because, as shown in the next section, technologies, management practices, and production systems are often adopted as packages, so separating out the effects of one technology versus others proves particularly challenging.

Adopters of all technologies, management practices, and production systems other than genetic selection and grazing held greater debt relative to assets compared with nonadopters. Farms adopting grazing had lower debt:asset ratios. Technologies and production systems with debt:asset ratios of at least 9 points greater for adopters than nonadopters were automatic take-offs, rbST, and milking 3 times daily. Although any of these alone (particularly rbST) would not be expected to significantly increase debt relative to assets, their use in more technologically intensive and larger farm systems could lead to greater debt.

\section{Complementary Relationships Among Technologies}

In most cases, adopters of technologies, management practices, and production systems were more likely than nonadopters to have adopted them as part of a package of other technologies, management practices, and production systems, with the exception of grazing. 
Table 2. United States Department of Agriculture Agricultural Resource Management Survey weighted means estimates of farm characteristics, by technology, in 2000 and $2005^{1}$

\begin{tabular}{|c|c|c|c|c|}
\hline \multirow[b]{2}{*}{ Item } & \multicolumn{2}{|c|}{2000} & \multicolumn{2}{|c|}{2005} \\
\hline & Nonadoption & Adoption & Nonadoption & Adoption \\
\hline \multicolumn{5}{|c|}{ Holding pen with udder washer } \\
\hline Milk cows, $\mathrm{n}$ & $88^{\mathrm{d}}$ & $525^{\mathrm{b}}$ & $116^{\mathrm{c}}$ & $700^{\mathrm{a}}$ \\
\hline Farmer age, yr & $49^{\mathrm{b}}$ & $50^{\mathrm{ab}}$ & $51^{\mathrm{a}}$ & $53^{\mathrm{a}}$ \\
\hline Farmer college degree, $\%$ & $10.0^{\mathrm{b}}$ & $18.4^{\mathrm{ab}}$ & $16.1^{\mathrm{a}}$ & $17.4^{\mathrm{a}}$ \\
\hline Debt:asset ratio & $0.19^{\mathrm{a}}$ & $0.22^{\mathrm{a}}$ & $0.14^{\mathrm{b}}$ & $0.17^{\mathrm{a}}$ \\
\hline Milk per cow, lb/yr & $15,559^{\mathrm{c}}$ & $16,524^{\mathrm{bc}}$ & $16,788^{\mathrm{b}}$ & $18,411^{\mathrm{a}}$ \\
\hline \multicolumn{5}{|c|}{ Milkers with automatic take-offs } \\
\hline Milk cows, n & $65^{\mathrm{c}}$ & $257^{\mathrm{a}}$ & $77^{\mathrm{b}}$ & $282^{\mathrm{a}}$ \\
\hline Farmer age, yr & $49^{\mathrm{b}}$ & $49^{\mathrm{b}}$ & $52^{\mathrm{a}}$ & $51^{\mathrm{ab}}$ \\
\hline Farmer college degree, $\%$ & $8.8^{\mathrm{c}}$ & $15.5^{\mathrm{b}}$ & $10.6^{\mathrm{c}}$ & $25.2^{\mathrm{a}}$ \\
\hline Debt:asset ratio & $0.18^{\mathrm{c}}$ & $0.22^{\mathrm{a}}$ & $0.11^{\mathrm{b}}$ & $0.20^{\mathrm{ac}}$ \\
\hline Milk per cow, lb/yr & $15.092^{\mathrm{c}}$ & $17,223^{\mathrm{b}}$ & $15,539^{\mathrm{c}}$ & $19,150^{\mathrm{a}}$ \\
\hline \multicolumn{5}{|l|}{ Genetic selection } \\
\hline Milk cows, $\mathrm{n}$ & $82^{\mathrm{c}}$ & $129^{\mathrm{b}}$ & $116^{\mathrm{b}}$ & $163^{\mathrm{a}}$ \\
\hline Farmer age, yr & $50^{\mathrm{ab}}$ & $49^{\mathrm{b}}$ & $52^{\mathrm{a}}$ & $51^{\mathrm{a}}$ \\
\hline Farmer college degree, $\%$ & $5.0^{\mathrm{c}}$ & $13.5^{\mathrm{ab}}$ & $11.2^{\mathrm{b}}$ & $17.2^{\mathrm{a}}$ \\
\hline Debt:asset ratio & $0.17^{\mathrm{ab}}$ & $0.20^{\mathrm{a}}$ & $0.14^{\mathrm{b}}$ & $0.15^{\mathrm{b}}$ \\
\hline Milk per cow, lb/yr & $14,230^{\mathrm{c}}$ & $16,377^{\mathrm{b}}$ & $13,276^{\mathrm{c}}$ & $17,716^{\mathrm{a}}$ \\
\hline \multicolumn{5}{|l|}{ Recombinant bST } \\
\hline Milk cows, n & $92^{\mathrm{d}}$ & $208^{\mathrm{b}}$ & $120^{\mathrm{c}}$ & $326^{\mathrm{a}}$ \\
\hline Farmer age, yr & $50^{\mathrm{b}}$ & $45^{\mathrm{c}}$ & $52^{\mathrm{a}}$ & $48^{\mathrm{bc}}$ \\
\hline Farmer college degree, $\%$ & $8.9^{\mathrm{c}}$ & $18.0^{\mathrm{a}}$ & $13.8^{\mathrm{ab}}$ & $27.8^{\mathrm{a}}$ \\
\hline Debt:asset ratio & $0.18^{\mathrm{b}}$ & $0.25^{\mathrm{a}}$ & $0.13^{\mathrm{c}}$ & $0.22^{\mathrm{a}}$ \\
\hline Milk per cow, lb/yr & $14,880^{\mathrm{d}}$ & $19,114^{\mathrm{b}}$ & $15,867^{\mathrm{c}}$ & $22,057^{\mathrm{a}}$ \\
\hline \multicolumn{5}{|l|}{ DHIA membership } \\
\hline Milk cows, $\mathrm{n}$ & $92^{\mathrm{c}}$ & $137^{\mathrm{b}}$ & $126^{\mathrm{b}}$ & $188^{\mathrm{a}}$ \\
\hline Farmer age, yr & $50^{\mathrm{ab}}$ & $48^{\mathrm{b}}$ & $52^{\mathrm{a}}$ & $50^{\mathrm{a}}$ \\
\hline Farmer college degree, $\%$ & $5.0^{\mathrm{c}}$ & $17.2^{\mathrm{a}}$ & $11.0^{\mathrm{b}}$ & $22.2^{\mathrm{a}}$ \\
\hline Debt:asset ratio & $0.17^{\mathrm{b}}$ & $0.22^{\mathrm{a}}$ & $0.13^{\mathrm{c}}$ & $0.16^{\mathrm{b}}$ \\
\hline Milk per cow, lb/yr & $14,088^{\mathrm{c}}$ & $17,496^{\mathrm{b}}$ & $15,065^{\mathrm{c}}$ & $19,094^{\mathrm{a}}$ \\
\hline \multicolumn{5}{|l|}{ Computerized feeding system } \\
\hline Milk cows, n & $96^{\mathrm{d}}$ & $296^{\mathrm{b}}$ & $124^{\mathrm{c}}$ & $536^{\mathrm{a}}$ \\
\hline Farmer age, yr & $49^{\mathrm{b}}$ & $50^{\mathrm{ab}}$ & $51^{\mathrm{a}}$ & $50^{\mathrm{ab}}$ \\
\hline Farmer college degree, $\%$ & $9.9^{\mathrm{b}}$ & $16.5^{\mathrm{abc}}$ & $15.4^{\mathrm{c}}$ & $24.6^{\mathrm{a}}$ \\
\hline Debt:asset ratio & $0.19^{\mathrm{a}}$ & $0.23^{\mathrm{a}}$ & $0.14^{\mathrm{b}}$ & $0.18^{\mathrm{a}}$ \\
\hline Milk per cow, lb/yr & $15,551^{\mathrm{c}}$ & $16,296^{\mathrm{bc}}$ & $16,592^{\mathrm{b}}$ & $20,753^{\mathrm{a}}$ \\
\hline \multicolumn{5}{|l|}{ Computerized milking system } \\
\hline Milk cows, $\mathrm{n}$ & $95^{\mathrm{d}}$ & $367^{\mathrm{b}}$ & $130^{\mathrm{c}}$ & $592^{\mathrm{a}}$ \\
\hline Farmer age, yr & $49^{\mathrm{b}}$ & $52^{\mathrm{ab}}$ & $51^{\mathrm{a}}$ & $52^{\mathrm{a}}$ \\
\hline Farmer college degree, $\%$ & $9.5^{\mathrm{b}}$ & $24.9^{\mathrm{ab}}$ & $15.9^{\mathrm{a}}$ & $18.9^{\mathrm{a}}$ \\
\hline Debt:asset ratio & $0.19^{\mathrm{a}}$ & $0.23^{\mathrm{a}}$ & $0.14^{\mathrm{b}}$ & $0.22^{\mathrm{a}}$ \\
\hline Milk per cow, lb/yr & $15,541^{\mathrm{c}}$ & $16,685^{\mathrm{bc}}$ & $16,708^{\mathrm{b}}$ & $20,238^{\mathrm{a}}$ \\
\hline \multicolumn{5}{|l|}{ Use of a nutritionist } \\
\hline Milk cows, $\mathrm{n}$ & $66^{\mathrm{d}}$ & $135^{\mathrm{b}}$ & $83^{\mathrm{c}}$ & $182^{\mathrm{a}}$ \\
\hline Farmer age, yr & $51^{\mathrm{b}}$ & $48^{\mathrm{d}}$ & $55^{\mathrm{a}}$ & $50^{\mathrm{b}}$ \\
\hline Farmer college degree, $\%$ & $4.6^{\mathrm{d}}$ & $13.4^{\mathrm{b}}$ & $10.1^{\mathrm{c}}$ & $18.5^{\mathrm{a}}$ \\
\hline Debt:asset ratio & $0.15^{\mathrm{b}}$ & $0.21^{\mathrm{a}}$ & $0.09^{\mathrm{c}}$ & $0.17^{\mathrm{b}}$ \\
\hline Milk per cow, lb/yr & $13,299^{\mathrm{c}}$ & $16,756^{\mathrm{b}}$ & $13,296^{\mathrm{c}}$ & $18,318^{\mathrm{a}}$ \\
\hline \multicolumn{5}{|l|}{ Grazing } \\
\hline Milk cows, $\mathrm{n}$ & $185^{\mathrm{b}}$ & $78^{\mathrm{d}}$ & $259^{\mathrm{a}}$ & $96^{\mathrm{c}}$ \\
\hline Farmer age, yr & $48^{\mathrm{b}}$ & $49^{\mathrm{b}}$ & $50^{\mathrm{b}}$ & $52^{\mathrm{a}}$ \\
\hline Farmer college degree, $\%$ & $10.7^{\mathrm{bc}}$ & $10.3^{\mathrm{c}}$ & $16.8^{\mathrm{a}}$ & $15.7^{\mathrm{ab}}$ \\
\hline Debt:asset ratio & $0.23^{\mathrm{a}}$ & $0.17^{\mathrm{b}}$ & $0.19^{\mathrm{b}}$ & $0.12^{\mathrm{c}}$ \\
\hline Milk per cow, lb/yr & $16.780^{\mathrm{b}}$ & $15,073^{\mathrm{c}}$ & $18,344^{\mathrm{a}}$ & $16,097^{\mathrm{bc}}$ \\
\hline \multicolumn{5}{|l|}{ Three-times-daily milking } \\
\hline Milk cows, n & $95^{\mathrm{c}}$ & $597^{\mathrm{a}}$ & $123^{\mathrm{b}}$ & $568^{\mathrm{a}}$ \\
\hline Farmer age, yr & $49^{\mathrm{b}}$ & $47^{\mathrm{b}}$ & $51^{\mathrm{a}}$ & $48^{\mathrm{ab}}$ \\
\hline Farmer college degree, $\%$ & $10.3^{\mathrm{c}}$ & $15.3^{\mathrm{abc}}$ & $14.4^{\mathrm{b}}$ & $39.1^{\mathrm{a}}$ \\
\hline Debt:asset ratio & $0.19^{\mathrm{b}}$ & $0.29^{\mathrm{a}}$ & $0.14^{\mathrm{c}}$ & $0.30^{\mathrm{a}}$ \\
\hline Milk per cow, lb/yr & $15,472^{\mathrm{d}}$ & $19,585^{\mathrm{b}}$ & $16,383^{\mathrm{c}}$ & $23,748^{\mathrm{a}}$ \\
\hline
\end{tabular}


Table 2 (Continued). United States Department of Agriculture Agricultural Resource Management Survey weighted means estimates of farm characteristics, by technology, in 2000 and $2005^{1}$

\begin{tabular}{|c|c|c|c|c|}
\hline \multirow[b]{2}{*}{ Item } & \multicolumn{2}{|c|}{2000} & \multicolumn{2}{|c|}{2005} \\
\hline & Nonadoption & Adoption & Nonadoption & Adoption \\
\hline \multicolumn{5}{|l|}{ Parlor } \\
\hline Milk cows, $\mathrm{n}$ & $57^{\mathrm{c}}$ & $201^{\mathrm{b}}$ & $56^{\mathrm{c}}$ & $252^{\mathrm{a}}$ \\
\hline Farmer age, yr & $49^{\mathrm{bc}}$ & $49^{\mathrm{c}}$ & $51^{\mathrm{ab}}$ & $52^{\mathrm{a}}$ \\
\hline Farmer college degree, $\%$ & $8.6^{\mathrm{c}}$ & $13.4^{\mathrm{b}}$ & $11.6^{\mathrm{bc}}$ & $20.6^{\mathrm{a}}$ \\
\hline Debt:asset ratio & $0.17^{\mathrm{b}}$ & $0.22^{\mathrm{a}}$ & $0.12^{\mathrm{c}}$ & $0.17^{\mathrm{b}}$ \\
\hline Milk per cow, lb/yr & $15,499^{\mathrm{b}}$ & $15,792^{\mathrm{b}}$ & $16,300^{\mathrm{b}}$ & $17,490^{\mathrm{a}}$ \\
\hline
\end{tabular}

This suggests significant technically complementary relationships among each. For each of the 11 technologies, the total number of other technologies, management practices, and production systems that differed in adoption rates for adopters and nonadopters of the reference technology at $P<0.10$ in either or both years were holding pen with udder washer, 9; milkers with automatic take-offs, 9; genetic selection, 8; rbST, 10; DHIA membership, 8; computerized feeding system, 10; computerized milking system, 9; use of a nutritionist, 9; grazing, 10; 3-times-daily milking, 10; and parlor, 7 . Thus, significant differences were found in the majority of cases for each technology, management practice, and production system.

Table 4 reports cases in which the adoption of a particular technology was at least 25 percentage points higher for adopters of the reference technology than for nonadopters of the reference technology in 2005 . Several examples are particularly noteworthy. Adopters of holding pens with udder washers had adoption rates at least 47 points higher than those of nonadopters for automatic take-offs and a parlor. Adopters of automatic take-offs had an adoption rate 47 points higher than nonadopters of automatic take-offs for parlors. Of genetic selection adopters, $51.8 \%$ were members of DHIA compared with $17.0 \%$ of nonadopters. Adopters of rbST had adoption rates at least 33 points higher than those of nonadopters for automatic take-offs, DHIA membership, and a parlor. Almost $90 \%$ of DHIA members used a nutritionist compared with $56.7 \%$ of DHIA nonmembers. Computerized feed delivery system adopters had adoption rates at least 33 points higher than those of nonadopters for automatic take-offs, rbST, and a parlor. Computerized milking system adopters had adoption rates at least 38 points higher than nonadopters for automatic take-offs and a parlor. Farmers milking 3 times daily had adoption rates at least 39 points higher than those milking twice daily for automatic take-offs, rbST, and DHIA membership. Of parlor adopters, $59.4 \%$ used automatic take-offs whereas only $15.7 \%$ of parlor non-

Table 3. United States Department of Agriculture Agricultural Resource Management Survey weighted means estimates, AI, embryo transfer, and sexed semen, $2005^{1}$

\begin{tabular}{lcc}
\hline Item & Nonadoption & Adoption \\
\hline AI & & \\
Farms, n & $9,710^{\mathrm{b}}$ & $42,527^{\mathrm{a}}$ \\
Milk cows, n & $116^{\mathrm{b}}$ & $163^{\mathrm{a}}$ \\
Farmer age, yr & 52 & 51 \\
Farmer college degree, $\%$ & $11.6^{\mathrm{b}}$ & $17.1^{\mathrm{a}}$ \\
Debt:asset ratio & 0.14 & 0.15 \\
Milk per cow, lb/yr & $13,302^{\mathrm{b}}$ & $17,714^{\mathrm{a}}$ \\
Embryo transfer and/or sexed semen & $48,804^{\mathrm{a}}$ & $5,433^{\mathrm{b}}$ \\
Farms, n & $148^{\mathrm{b}}$ & $210^{\mathrm{a}}$ \\
Milk cows, n & $52^{\mathrm{a}}$ & $48^{\mathrm{b}}$ \\
Farmer age, yr & $13.2^{\mathrm{b}}$ & $40.8^{\mathrm{a}}$ \\
Farmer college degree, $\%$ & 0.14 & 0.17 \\
Debt:asset ratio & $16,418^{\mathrm{b}}$ & $20,995^{\mathrm{a}}$ \\
Milk per cow, lb/yr & &
\end{tabular}

${ }^{a, b}$ Means within rows with different superscripts differ, $P<0.10$.

${ }^{1}$ The $t$-statistics are based on 1,804 observations using weighting techniques described in the Dubman (2000) program. 
Table 4. United States Department of Agriculture Agricultural Resource Management Survey weighted means estimates, percentages of technology adopters and nonadopters adopting other technologies, management practices, and production systems, reporting those with $>25$ percentage point differences, 2005

\begin{tabular}{lcc}
\hline Technology, practice, or system & Nonadoption, $\%$ & Adoption, $\%$ \\
\hline Holding pen with udder washer & & \\
Milkers with automatic take-offs & 34.4 & 81.7 \\
Grazing & 66.8 & 31.8 \\
Parlor & 46.6 & 97.1 \\
Milkers with automatic take-offs & & \\
$\quad$ Parlor & 32.4 & 79.1 \\
Genetic selection & & \\
DHIA membership & 17.0 & 51.8 \\
Nutritionist used & 46.1 & 77.1 \\
Recombinant bST & & \\
Milkers with automatic take-offs & 31.3 & 68.8 \\
DHIA membership & 39.2 & 76.4 \\
Nutritionist used & 67.0 & 95.0 \\
Milking 3 times daily & 2.1 & 31.1 \\
Parlor & 44.4 & 77.8 \\
DHIA membership & & \\
Nutritionist used & 56.7 & 89.6 \\
Computerized feeding system & & \\
Milkers with automatic take-offs & 34.4 & 77.0 \\
Recombinant bST & 14.0 & 49.3 \\
Grazing & 66.8 & 35.1 \\
Parlor & 47.1 & 86.2 \\
Computerized milking system & & \\
Milkers with automatic take-offs & 34.5 & 92.3 \\
Recombinant bST & 15.1 & 43.0 \\
Grazing & 66.0 & 37.9 \\
Milk 3 times per day & 5.3 & 36.8 \\
Parlor & 47.9 & 85.9 \\
Use of a nutritionist & & 56.8 \\
Grazing membership & 16.7 & 57.6 \\
Three times daily milking & & \\
Milkers with automatic take-offs & 33.4 & 92.9 \\
Recombinant bST & 12.3 & 84.2 \\
DHIA membership & 42.7 & 95.8 \\
Nutritionist used & 69.8 & 39.7 \\
Grazing & 66.4 & 80.8 \\
Parlor & 47.6 & 59.4 \\
Marlor & & \\
Grazing & 15.7 & \\
\hline
\end{tabular}

adopters used automatic take-offs. Grazers had lower adoption rates $(P<0.10)$ of all but 2 technologies in 2005 , although all differences were less than 25 percentage points, so they are not included in Table 4.

What makes a particularly strong impression is that, for each technology, management practice, and production system, adoption rate correlations are not only statistically significant, but the magnitudes of the differences are, in many cases, quite large, with adoption rates for a technology being in some cases 3 times greater if a second technology was adopted. Highly complementary are parlor and automatic takeoff adoption; rbST and 3-times-daily milking; 3-timesdaily milking and automatic take-off adoption; use of a nutritionist and DHIA membership; automatic take-off and computerized milking system adoption (both of which may be integrated into the same machine); computerized feed delivery system and automatic take-off adoption; holding pen and udder washer and automatic take-off adoption; and holding pen and udder washer and parlor adoption. Multiple technologies and management practices are likely to be adopted as part of an overall production system.

\section{Additional Measures of Structural Change: 2000 to 2005}

Table 1 provides additional insight into dairy industry structural change during 2000 to 2005 . Dairy farms grew, on average, from 112 to 154 cows. The average age of dairy farmers increased from 49 to 51 yr. Percentages of farmers with 4-yr college degrees increased from 10.4 to $16.1 \%$. Dairy farmers were less leveraged in 2005 than 2000. Average milk produced per cow increased from 15,611 to 16,894 pounds $(7,081$ to $7,663 \mathrm{~kg})$. Overall, 5-yr trends show increases in farm size and an aging set of more educated and productive farmers.

\section{DISCUSSION}

Changes in the US dairy industry have been significant whether examined using farm numbers, farm size, productivity, or technology adoption. From 2000 to 2005 , average dairy farm size grew by $37.5 \%$ in cows, and cow productivity increased $8.2 \%$. Thus, the figures not only show growth in farm size, but also imply increased intensity, as cow productivity increased while land inputs were de-emphasized.

Technology adoption trends were particularly striking. Over the period, increases were seen in the use of automatic take-offs, milking 3 times daily, and genetic selection. Somewhat surprising was that no significant changes were found in other technological innovations, management practices, and systems, such as udder washers, rbST, DHIA membership, computerized feed delivery systems, computerized milking systems, the use of a nutritionist, or grazing, although many increased in terms of percentage of milk produced as small farms exited while large adopters continued farming. Reasons beyond the scope of this study may explain why each of these technologies, management practices, or production systems remained relatively stable over the period of study, and each deserves significant research to determine influences on farm profitability or other reasons preventing more farmers from adopting.

Adopters of each of the technologies, management practices, and production systems (besides grazing) tend to be adopters of the other technologies, practices, and systems. This suggests at least 2 things. First, the 
technologies complement one another and may be used in an overall systems approach. Second, each was used more extensively by larger farms, so there appear to be significant economies of size associated with adoption of each. This suggests that as farm sizes continue to grow, larger farms will be the adopters of these technologies, whether or not they are truly technically complementary with one another.

\section{CONCLUSIONS}

Increases in the use of several technologies, management practices, and production systems were seen over the period 2000-2005 while usage of others either remained the same or decreased. For dairy industry researchers focused on determining the effect of a particular technology or management practice on profitability or productivity, it is clear from this analysis that singling out a particular innovation and evaluating its impact on profitability or productivity will lead to upward bias unless accounting for the effect of other technologies using proper corrections for selection bias. Each of the technologies and management practices was associated with higher milk cow productivity and enterprise net returns, but adopters of a particular technology were also the adopters of other technologies and management practices, so sorting out the influence of a particular technology is a significant challenge. Thorough examinations that adequately isolate the technology of interest are vital to fully understanding the dynamics of adoption.

\section{REFERENCES}

Amos, H. E., T. Kiser, and M. Lowenstein. 1985. Influence of milking frequency on productive and reproductive efficiencies of dairy cows. J. Dairy Sci. 68:732-739.

Barber, K. A. 1983. Maximizing the impact of dairy and beef bulls through breeding technology. J. Dairy Sci. 66:2661-2671.

Busem, R. C., and D. W. Bromley. 1975. Applied Economics. Iowa State Univ. Press, Ames.

Chastain, J. P., and D. J. Reinemann. 1995. Automated flat parlors: A cost effective method to improve labor efficiency for small dairy herds." Paper no. 953497 in Proc. Am. Soc. Agric. Eng., Chicago, IL. ASAE, St. Joseph, MI.

DePeters, E. J., N. E. Smith, and J. Acedo-Rico. 1985. Three or two times daily milking of older cows and first lactation cows for the entire lactation. J. Dairy Sci. 68:123-132.

De Vries, A., M. Overton, J. Fetrow, K. Leslie, S. Eicker, and G. Rogers. 2008. Exploring the impact of sexed semen on the structure of the dairy industry. J. Dairy Sci. 91:847-856.

Dubman, R.W. 2000. Variance estimation with USDA's farm costs and returns surveys and agricultural resource management study surveys. Staff paper AGES 00-01. USDA Economics Research Service, Washington, DC.

El-Osta, H. S., and J. D. Johnson. 1998. Determinants of financial performance of commercial dairy farms. Tech. Bulletin no. 1859. USDA Economics Research Service, Washington, DC.
El-Osta, H. S., and M. J. Morehart. 2000. Technology adoption and its impact on production performance of dairy operations. Rev. Agric. Econ. 22:477-498.

Erdman, R. A., and M. Varner. 1995. Fixed yield responses to increased milking frequency. J. Dairy Sci. 78:1199-1203.

Feder, G., R. E. Just, and D. Zilberman. 1985. Adoption of agricultural innovations in developing countries. Econ. Dev. Cult. Change $33: 255-298$.

Foltz, J., and H. H. Chang. 2002. The adoption and profitability of rbST on Connecticut dairy farms. Am. J. Agric. Econ. 84:10211032.

Foote, R. H. 1996. Review: Dairy cattle reproductive physiology research and management-Past progress and future prospects. J. Dairy Sci. 79:980-990.

Gillespie, J., T. Mark, C. Sandretto, and R. Nehring. 2009a. Computerized technology adoption among farms in the U.S. dairy industry. J. Am. Soc. Farm Managers Rural Apprais. 31:216-224.

Gillespie, J., R. Nehring, C. Hallahan, and C. Sandretto. 2009b. Pasture-based dairy systems: Who are the producers and are their operations more profitable than conventional dairies? J. Agric. Resour. Econ. 34:412-427.

Gisi. D. D., E. J. DePeters, and C. L. Pelissier. 1986. Three times daily milking of cows in California dairy herds. J. Dairy Sci. 69:863-868.

Hare, E., H. D. Norman, and J. R. Wright. 2004. Duration of herd participation in dairy herd improvement milk recording in the United States. J. Dairy Sci. 87:2743-2747.

Harrison, J. H., R. A. White, A. Sutton, T. Applegate, G. Erickson, R. Burns, and G. Carpenter. 2007. An introduction to Natural Resource Conservation Service (NRCS) feed management practice standard 592. Feed Management Education Project, USDA-NRCS Fact Sheet. NRCS, Washington, DC.

Hillers, J. K., S. C. Thonney, and C. T. Gaskins. 1982. Economic comparison of breeding dairy cows artificially versus naturally. J. Dairy Sci. 65:861-865.

Johnson, N. L., and V. W. Ruttan. 1997. The diffusion of livestock breeding technology in the US: Observations on the relationship between technical change and industry structure. J. Agribus. 15:19-35

Katsumata, K., and L. Tauer. 2008. Empirical analysis of stanchion and parlor milking cost on New York dairy farms. J. Agric. Appl. Econ. 40:719. (Abstr.)

Kelly, A. L. 2001. Chapter 2: Primary milk production. Pages 40-47 in Mechanization and Automation in Dairy Technology. T. Y. Adnam and B. A. Law, ed. Sheffield Acad. Press, Sheffield, UK.

MacDonald, J. M., E. J. O'Donoghue, W. McBride, R. Nehring, C. L. Sandretto, and R. Mosheim. 2007. Profits, costs and the changing structure of dairy farming. ERR-47. USDA Economics Research Service, Washington, DC

Manchester, A. C., and D. P. Blayney. 1997. The structure of dairy markets: Past, present, future. Agricultural Economic Report 757. USDA Economics Research Service, Washington, DC.

McBride, W. D., S. Short, and H. El-Osta. 2004. The adoption and impact of bovine somatotropin on U.S. dairy farms. Rev. Agric. Econ. 26:472-488.

McCaffree, J. D., R. W. Everett, H. R. Ainslie, and B. T. McDaniel. 1974. Economic value of dairy herd improvement programs. J. Dairy Sci. 57:1420-1422.

Reimund, D. A., C. V. Moore, and J. R. Martin. 1977. Factors affecting structural change in agricultural subsectors: Implications for research. South. J. Agric. Econ. 9:11-19.

Rotz, C. A., C. U. Coiner, and K. J. Soder. 2003. Automatic milking systems, farm size, and milk production. J. Dairy Sci. 86:41674177.

Shook, G. E. 2006. Major advances in determining appropriate selection goals. J. Dairy Sci. 89:1349-1361.

Short, S.D. 2000. Structure, management, and performance characteristics of specialized dairy farm businesses in the United States. Agric handbook no. 720. USDA Economics Research Service, Washington, DC. 
Short, S. D. 2004. Characteristics and production costs of US dairy operations. Statistical Bulletin no. 974-6. USDA Economics Research Service, Washington, DC.

Sorensen, B. A., D. D. Muir, and C. H. Knight. 2001. Thrice-daily milking throughout lactation maintains epithelial integrity and thereby improves milk protein quality. J. Dairy Res. 68:15-25.

Spain, J. N., and M. Witherspoon. 1994. Why Missouri dairy farms discontinue dairy herd improvement association testing programs. J. Dairy Sci. 77:1141-1145.

Tauer, L. W. 1998. Cost of production for stanchion versus parlor milking in New York. J. Dairy Sci. 81:567-569.

Tauer, L. W. 2005. The impact of recombinant bovine somatotropin on dairy farm profits: A switching regression analysis. AgBioForum 8:33-39.

Tauer, L. W., and A. K. Mishra. 2006. Dairy farm cost efficiency. J. Dairy Sci. 89:4937-4943.

Tranel, L. 2008. Automatic take-offs-Are they for you? Iowa State Univ. Fact Sheet LT-06. Iowa State University, Ames.

Tucker, W. B., B. J. Rude, and S. Wittayakun. 2001. Case study: Performance and economics of dairy cows fed a corn silage-based total mixed ration or grazing annual ryegrass during mid to late lactation. Prof. Anim. Sci. 17:195-201.

Tyler, H., and M. Ensminger. 2005. Dairy Cattle Science. PrenticeHall, Upper Saddle River, NJ.
USDA-National Agricultural Statistics Service (NASS). 2000. Agricultural Statistics. http://www.nass.usda.gov/Publications/Ag_Statistics/2000/index.asp. USDA-NASS, Washington, DC.

USDA-National Agricultural Statistics Service (NASS). 2009. Land, Land in Farms, and Livestock Operations: 2008 Summary, February. USDA-NASS, Washington, DC

van Arendonk, J. M., and P. Bijma. 2003. Factors affecting commercial application of embryo technologies in dairy cattle in EuropeA modeling approach. Theriogenology 59:635-649. PubMed

Weersink, A., and L. W. Tauer. 1991. Causality between dairy farm size and productivity. Am. J. Agric. Econ. 73:1138-1145.

Weigel, K. A. 2004. Exploring the role of sexed semen in dairy production systems. J. Dairy Sci. 87(E Suppl.):E120-E130.

White, R.A., Harrison, J.H., Sutton, A., Applegate, T., Erickson, G., Burns, R., and Koelsch, R. 2007. Five steps to the development and implementation of a feed management plan. Feed Management Educ. Proj., USDA-NRCS Fact Sheet 5-25-2007. Natural Resource Conservation Service, Washington, DC.

White, S. L., G. A. Benson, S. P. Washburn, and J. T. Green Jr. 2002. Milk production and economic measures in confinement or pasture systems using seasonally calved Holstein and Jersey cows. J. Dairy Sci. 85:95-104. 